\title{
The T-shaped “axe” from Northeast Honduras: Observations on chronology and function of a pre-Columbian stone tool
}

\author{
Paul F. Healy, Daniel Savage \\ Department of Anthropology, Trent University. Peterborough, Ontario, K9J 7B8, Canada. \\ Email: Healy: phealy@trentu.ca; Savage: dan.usavage@gmail.com
}

\begin{abstract}
:
This paper provides a description and analysis of a distinctive type of pre-Columbian stone tool, usually termed a T-shaped axe, found almost exclusively in Northeast Honduras, Central America. There have been very few detailed or technical studies of lithics from Honduras. Early archaeological research and the current understanding of the regional prehistory are included, with Northeast Honduras viewed as a frontier zone located between the Mesoamerican and Isthmo-Columbian culture areas. Our study examines, in particular, a collection of these tools curated today at the Cambridge University Museum of Archaeology and Anthropology (CUMAA). The 39 (whole and fragmentary) specimens were collected between 1937 and 1939, from the Bay Islands, Northeast Honduras, but have never been published. This paper classifies the collection specimens into five varieties, based on morphology, with sample statistics, form dimensions, and illustrations provided for each. Manufacturing technology is primarily percussion flaking. The tool type is compared with similar specimens excavated and described from the Bay Islands and adjacent Honduran mainland, and with similar appearing implements from elsewhere in Central America. Insights about the possible age and function of these unusual, and distinctive, lithics are included. Based on preliminary macroscopic and microscopic analyses, it is concluded that the tools may have been employed as agricultural implements (hoes or spades), primarily for digging activities, rather than as axes or weapons used for cutting and slicing. It is most likely that these implements first appeared about $800 \mathrm{CE}$, and continued in use until at least $1400 \mathrm{CE}$. The tool type is most probably a local (not imported) product. More functional analysis is encouraged.
\end{abstract}

Keywords: archaeology of Central America; Honduras; lithics; T-shaped axes; chronology; microscopic analysis; tool function

\section{Introduction}

While archaeologists have completed comprehensive analyses of early ceramics, faunal remains, and even ancient musical instruments of Honduras (Dennett 2007; Epstein 1957; Healy 1983; 1993; Healy et al. 2010; Henderson \& Beaudry-Corbett 1993; Reyes Mazzoni \& Véliz 1974; Véliz 1978), by sharp contrast there have been few modern studies of preColumbian lithics (Healy 2012). This paper identifies one major lithic type from the region of

Published by the School of History, Classics and Archaeology, University of Edinburgh ISSN: 2055-0472. URL: http://journals.ed.ac.uk/lithicstudies/ 
Northeast Honduras, with observations on and analysis of tool chronology, form, and function. It is, of course, crucial to classify and study early stone tools to provide insights to the full range of past economic activities, such as trade, agriculture, and subsistence, in order to provide a more complete picture of early life in this poorly understood part of Lower Central America.

\subsection{Previous research}

The archaeology of Northeast Honduras, defined here as the geographic region composed of the modern political departments of Colon and the Bay Islands, is less well known than most parts of Central America (Figure 1). The knowledge limitations are due, to a considerable degree, to the remoteness of the region, which has inhibited modern fieldwork and exploration (Begley 1999; Cuddy 2007; Healy 1984a; b). Based on a limited number of recent ceramic studies, it is clear that pre-Columbian culture history in this region extends to about 1000 BCE, a time known as the Cuyamel period (Healy 1974; 1993). Archaeological evidence for this early era is largely restricted to pottery recovered from remote cave sites (Healy 1974; Reyes Mazzoni \& Véliz 1974). More widespread indigenous settlement, presumably based on agriculture, is present on both the Bay Islands and adjacent mainland (Department of Colon) by the third century CE, at the start of the Selin period (300-900 CE) (Healy 1978a: 63). Small-scale village settlements, such as the sites of Williams Ranch (HCN-4) and Selin Farm (H-CN-5), were marked by modest earthen or earth-and-shell constructions (house mounds) characteristic of the region at this time (Healy 1975; 1978a: $65)$.

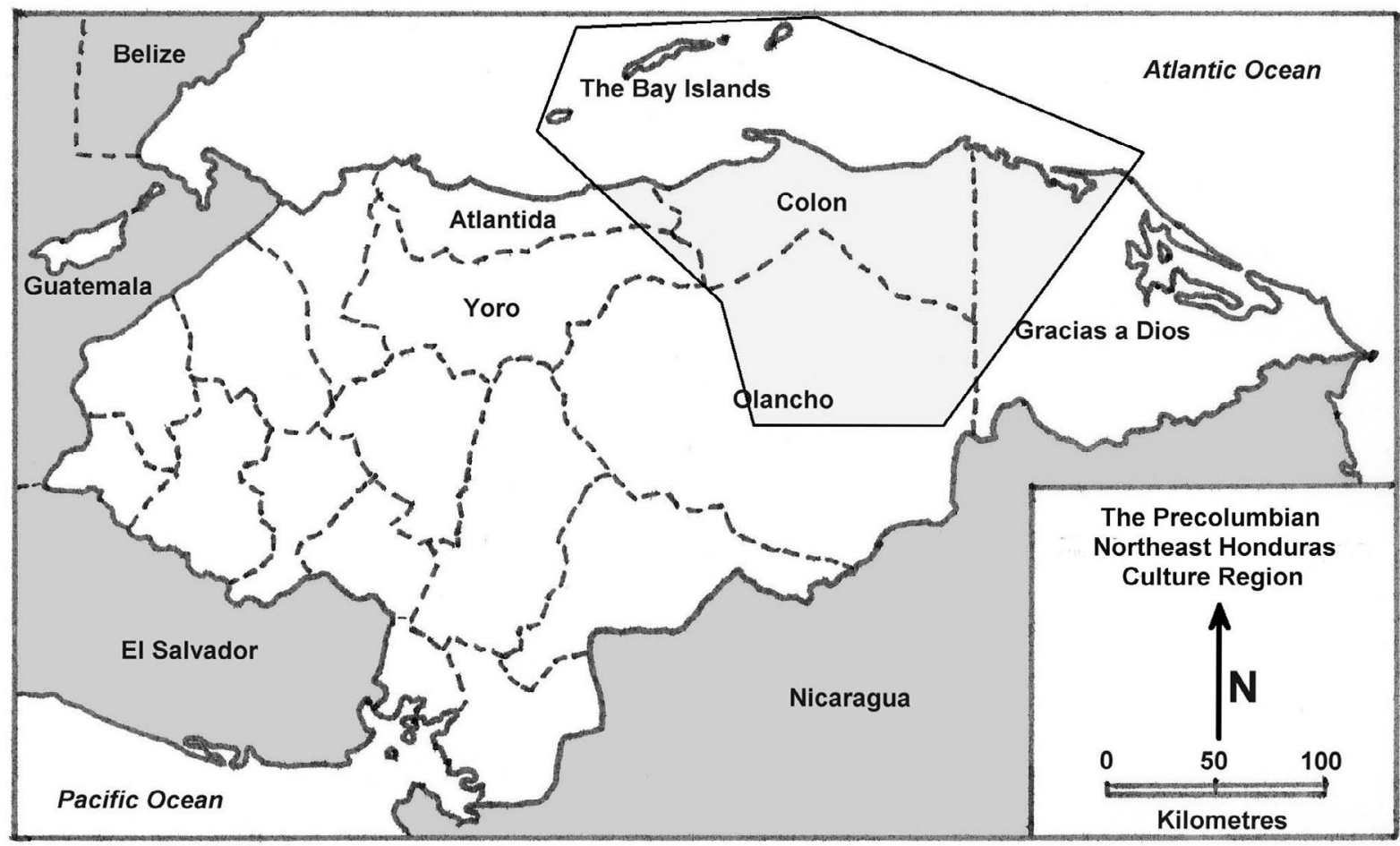

Figure 1. Map of Honduras, detailing the Northeast Honduras Region, including the political Department of Bay Islands, Colon, northern Olancho and western Gracias a Dios (after Healy \& Dennett 2006).

Ethnic affiliation of these earliest populations remains unclear, but some aspects of the material culture (especially the ceramics) appear to have been influenced at least by more complex cultures of the neighbouring Mesoamerican culture area (Mexico, Guatemala, Belize) to the west (Healy 1984b). In addition to farming, most likely the growing of maize 
(Zea mays), there was an extensive exploitation of local fauna, through hunting, fishing, and shellfish gathering (Healy 1983). The village populations at this time, perhaps no more than 50-250 people each, were likely organized as low-level chiefdoms (Healy 1978a: 65).

Between 900-1520 CE, Northeast Honduras undergoes a significant cultural transformation, with the appearance of demonstrably different material culture in the region, and with hints of influence from cultures located far to the south, from the Isthmo-Colombian culture area (Nicaragua, Costa Rica, Panama, and Colombia) (Dennett 2007; Healy 1992; Healy \& Dennett 2006; Hoopes 2005; Hoopes \& Fonseca 2003). By this time, sites such as Rio Claro (H-CN-12) in the Aguan River Valley are larger and more complex in spatial organization (Healy 1978b; 1984a; 1992). There are indications of the tuber manioc (Manihot esculenta), or cassava, being in use in the region, in addition to maize, by the time of European contact (Begley 2000: 43; Healy \& Dennett 2006: 9). Manioc was a staple of the Chibchan-speaking indigenous cultures to the south of what is today Honduras (Hoopes 2005; but also see Sheets et al. 2012). By the time of the sixteenth century CE conquest by the Spanish, Northeast Honduras is known to have been inhabited by a native population termed the Paya (presumed ancestors to the modern day Pech), who appear to have spoken a Chibchan-derived language (Constenla Umaña 1991; 1995). While the population was still organized politically as a chiefdom, public constructions (corporate works) now tended to be larger, more formally organized earth-and-stone platforms, with some site fortifications, paved stone walkways, and the presence of long-distance trade items (copper, obsidian, exotic ceramics). These developments hint at the evolution of more complex paramount chiefdoms in the region (see Hoopes 2005, for other examples).

Importantly, then, Northeast Honduras straddles the frontier zone between the Mesoamerican and the Isthmo-Colombian culture areas of Central America (Healy 1974; 1984c; Healy \& Dennett 2006; Hoopes \& Fonseca 2003; see also Willey 1959), and its prehistory, spread over a period of more than 2000 years, reflects this duality of cultural stimulation (Healy 1984a; 1992). Today, there are many unanswered questions about this remote (and understudied) part of Central America. Here we undertake an examination of a special class of lithic implements directly, and perhaps uniquely, associated with this poorly known region. These lithics are part of a collection housed and curated today at the Cambridge University Museum of Archaeology and Anthropology (CUMAA) (Cantwell et al. 1981).

\section{The Lord Moyne \& R.W. Feachem Archaeological Collection (Bay Islands, Honduras)}

This large assemblage of ceramic, lithic, shell, bone, and metal artifacts was collected by the then well-known British diplomat, Lord Moyne, from the Bay Islands of Honduras in 1937. Walter Edward Guinness, $1^{\text {st }}$ Baron Moyne (Lord Moyne), was a well-known AngloIrish politician, businessman, and diplomat during the reign of King George VI of England. Following his extensive travels and archaeological collecting in the Caribbean, just prior to the outbreak of World War II, Lord Moyne was appointed the British Minister of State for the Middle East. He was a member of Prime Minister Winston Churchill's War Cabinet from 1940-1944, and was assassinated in 1944, by a dissident political group.

The already large collection was augmented two years later, in 1939, just prior to the start of World War II, by Cambridge University archaeologist R.W. de F. Feachem (Feachem \& Braunholtz 1938; Feachem 1940). Importantly, Feachem (1947) completed a Master's thesis that examined much of the collection. Unfortunately, he was hampered at this time by a lack of detailed stratigraphic and provenience information for almost all of the specimens, and 
by a paucity of published information about the archaeology of the region, which limited his conclusions.

The online, digital catalogue of artifacts from the CUMAA lists nearly 3000 artifacts from the Moyne-Feachem Bay Islands archaeological collection. Items range from individual specimens, such as single ceramic lugs, or individual sherds, to larger sets of greenstone pendants, stone mace heads, ceramic musical instruments, etc. (Healy 2012; Healy et al. 2010). The study collection, unfortunately, stems from various unspecified site locations on the Bay Islands. One of the most unusual categories of the lithic remains in this large museum collection is (what has often been termed) the Ace of Spades or T-shaped axe, the focus of our discussion herein.

\subsection{The T-shaped axe}

In 2012, one of the authors (Healy) examined more than three dozen chipped stone axes from the Moyne-Feachem archaeological collection (Table $1 \& 2$ ). These implements (whole specimens and fragments) have an elongated, tang-like base, usually rounded, with a broad flaring, or even out-flaring, flat blade. The tang base was, presumably, hafted to a wood handle, while the flat blade served as the business end of the implement.

Table 1. Combined sample statistics for T-shaped axes in the Moyne-Feachem collection from the Bay Islands, Northeast Honduras (Cambridge University Museum of Archaeology and Anthropology). Incomplete specimens (marked by "?" for individual items in Table 2) are not included in the calculation of sample statistics.

\begin{tabular}{lcccc}
\hline Sample statistics* & Length $(\mathbf{c m})$ & Width $(\mathbf{c m})$ & Thickness $(\mathbf{m m})$ & Weight $(\mathbf{g})$ \\
\hline Min & 8.2 & 9.0 & 14.6 & 155.3 \\
Max & 20.0 & 16.3 & 30.5 & 567.0 \\
Mean & 14.5 & 12.1 & 22.7 & 326.7 \\
St. Dev. & 2.6 & 2.0 & 4.2 & 112.4 \\
\hline
\end{tabular}

Based on this analysis it is clear that these curious early tools have a fairly uniform shape, size, and weight. Based on our comparative study, they appear to have a very restricted geographic distribution in Central America. The tools are quite distinctive and easily recognized. Length (measured from the base of the tang to blade tip), based on 26 whole specimens in the CUMAA collection, ranged from 8.2-20 cm, with an average size of $13.4 \mathrm{~cm}$ long. Width (measured as the maximum distance from the outer edge of each blade shoulder), based on 25 whole specimens, ranged from $9.0-16.3 \mathrm{~cm}$, with an average size of $12.2 \mathrm{~cm}$ wide. Thickness (measured at the greatest thickness of the blade), based on 28 whole (or nearly whole) specimens, ranged from $10.8-30.5 \mathrm{~mm}$, with an average of $22.3 \mathrm{~mm}$ thick. The weight, based on 25 whole specimens, ranged from 155.3-502.2 g with an average of $326.7 \mathrm{~g}$. The tang on larger specimens (measured from base of the stem to the out-flaring shoulders) measured as much as $16.5 \mathrm{~cm}$ long, and as much as $8 \mathrm{~cm}$ wide. However, these would have been exceptional examples. An average tang length and width was probably closer to half these measurements (e.g., about $8 \mathrm{~cm}$ long, $4 \mathrm{~cm}$ wide).

The specimens can be sub-divided into five varieties, based on the form of the blade: Pointed (Figure 2), Rounded or Crescent (Figure 3), Wide (or T-shaped) (Figure 4), Squared (Figure 5), and Irregular (e.g., V-shaped, or L-shaped blades). The most common form in the Moyne-Feachem collection is the Pointed variety ( $\mathrm{n}=10 ; 40 \%$ of whole specimens), followed in popularity by Rounded ( $\mathrm{n}=7 ; 28 \%$ ), followed by Wide (or T-shaped) ( $\mathrm{n}=3 ; 12 \%$ ), Irregular $(\mathrm{n}=3 ; 12 \%)$ and Squared $(\mathrm{n}=2 ; 8 \%)$ varieties as the least common. Other broken specimens $(n=13)$ were harder to classify, but (based on macroscopic examination) these were, most likely, originally pointed varieties. Indeed, it is quite possible that the template form for most of these crude implements was pointed and, as the tool was used and 
increasingly worn down, they simply morphed into Rounded, or Wide (or T-shaped), Squared, or other Irregular shapes. Most blades show significant alteration and signs of damage, hinting at rough use and handling. As such, a ritual use or ceremonial function for the implements, suggested by some (see below) seems unlikely.

Table 2: Individual axe specimens and dimensions from the Moyne-Feachem collection (Cambridge University Museum of Archaeology and Anthropology). Measurements followed by a "?" represent incomplete dimensions.

\begin{tabular}{|c|c|c|c|c|c|}
\hline Cat. No. & Variety & Length $(\mathrm{cm})$ & Width $(\mathrm{cm})$ & Thickness (mm) & Weight (g) \\
\hline 1946.166A & Rounded & 10.9 & 9.0 & 23.7 & 155.3 \\
\hline 1946.166B & Rounded & 12.0 & 10.0 & 22.3 & 258.5 \\
\hline $1946.166 C$ & Wide or $T$ & 11.7 & 9.2 & 20.5 & 210.8 \\
\hline 1946.166D & (incomplete) & 10.9 & $7.2 ?$ & 10.8 & $82.5 ?$ \\
\hline 1946.166E & Irregular & 14.0 & 11.0 & 30.2 & 346.6 \\
\hline $1946.166 \mathrm{~F}$ & Rounded & 15.5 & 11.0 & 26.4 & 386.8 \\
\hline 1946.166G & Irregular & 16.5 & 12.3 & 23.1 & 274.9 \\
\hline $1946.166 \mathrm{H}$ & (incomplete) & 21.9? & $18.5 ?$ & 21.1? & $577.2 ?$ \\
\hline $1946.166 \mid$ & (unavailable) & --- & --- & --- & --- \\
\hline 1946.166J & Rounded & 16.4 & 14.3 & 20.8 & 362.8 \\
\hline 1946.166K & Squared & 17.0 & 11.2 & 28.0 & 567.0 \\
\hline 1946.166L & Pointed & 16.7 & 12.4 & 30.5 & 524.0 \\
\hline $1946.166 \mathrm{M}$ & Pointed & 15.5 & 14.0 & 20.3 & 322.5 \\
\hline $1946.166 \mathrm{~N}$ & Pointed & 13.5 & 11.3 & 16.6 & 199.4 \\
\hline 1946.1660 & Rounded & 10.3 & 11.0 & 23.6 & 160.8 \\
\hline $1946.166 \mathrm{P}$ & Pointed & 16.5 & 16.0 & 22.4 & 474.4 \\
\hline 1946.166Q & Pointed & 17.3 & 11.8 & 26.3 & 466.9 \\
\hline Z35258A & Pointed & 15.7 & 12.8 & 25.5 & 361.3 \\
\hline Z35258B & Squared & 14.9 & 9.7 & 19.0 & 302.1 \\
\hline Z35258C & (incomplete) & $11.2 ?$ & $7.5 ?$ & $11.5 ?$ & $135.1 ?$ \\
\hline Z35258D & (incomplete) & $12.0 ?$ & $7.3 ?$ & $18.9 ?$ & $212.4 ?$ \\
\hline Z35258E & (incomplete) & $16.5 ?$ & $8.3 ?$ & $13.1 ?$ & $152.5 ?$ \\
\hline Z35258F & Pointed & 17.0 & 12.2 & 19.3 & 367.5 \\
\hline Z35258G & Pointed & 13.2 & 15.0 & 23.5 & 330.8 \\
\hline Z35258H & Pointed & 14.0 & 14.5 & 15.9 & 232.0 \\
\hline Z35258I & Rounded & 13.2 & 11.7 & 21.7 & 309.0 \\
\hline Z35258J & (incomplete) & $13.6 ?$ & $9.6 ?$ & 24.8 & 269.1? \\
\hline Z35258K & Pointed & 15.5 & 10.1 & 20.5 & 326.5 \\
\hline Z35259A & (incomplete) & $15.4 ?$ & $9.3 ?$ & $19.9 ?$ & $260.3 ?$ \\
\hline Z35259B & Irregular & 20.0 & 12.5 & 25.4 & 502.2 \\
\hline Z35259C & (incomplete) & $16.6 ?$ & $10.3 ?$ & $24.2 ?$ & $320.4 ?$ \\
\hline Z35259D & (incomplete) & $10.6 ?$ & $10.0 ?$ & $15.1 ?$ & 179.1? \\
\hline Z35260A & (incomplete) & $11.2 ?$ & $10.4 ?$ & $16.7 ?$ & $153.8 ?$ \\
\hline Z35260B & Wide or $\mathrm{T}$ & 12.8 & 12.1 & 19.5 & 226.9 \\
\hline Z35260C & (incomplete) & $17.9 ?$ & $16.3 ?$ & $30.3 ?$ & $536.4 ?$ \\
\hline Z35260D & Rounded & 8.2 & 12.3 & 28.3 & 245.5 \\
\hline Z35260E & (incomplete) & $15.2 ?$ & $16.5 ?$ & $26.6 ?$ & $402.4 ?$ \\
\hline Z35260F & Wide or $\mathrm{T}$ & 13.3 & 16.3 & 14.6 & 251.8 \\
\hline Z35260G & (incomplete) & $13.7 ?$ & $13.5 ?$ & 27.0 & $384.3 ?$ \\
\hline
\end{tabular}




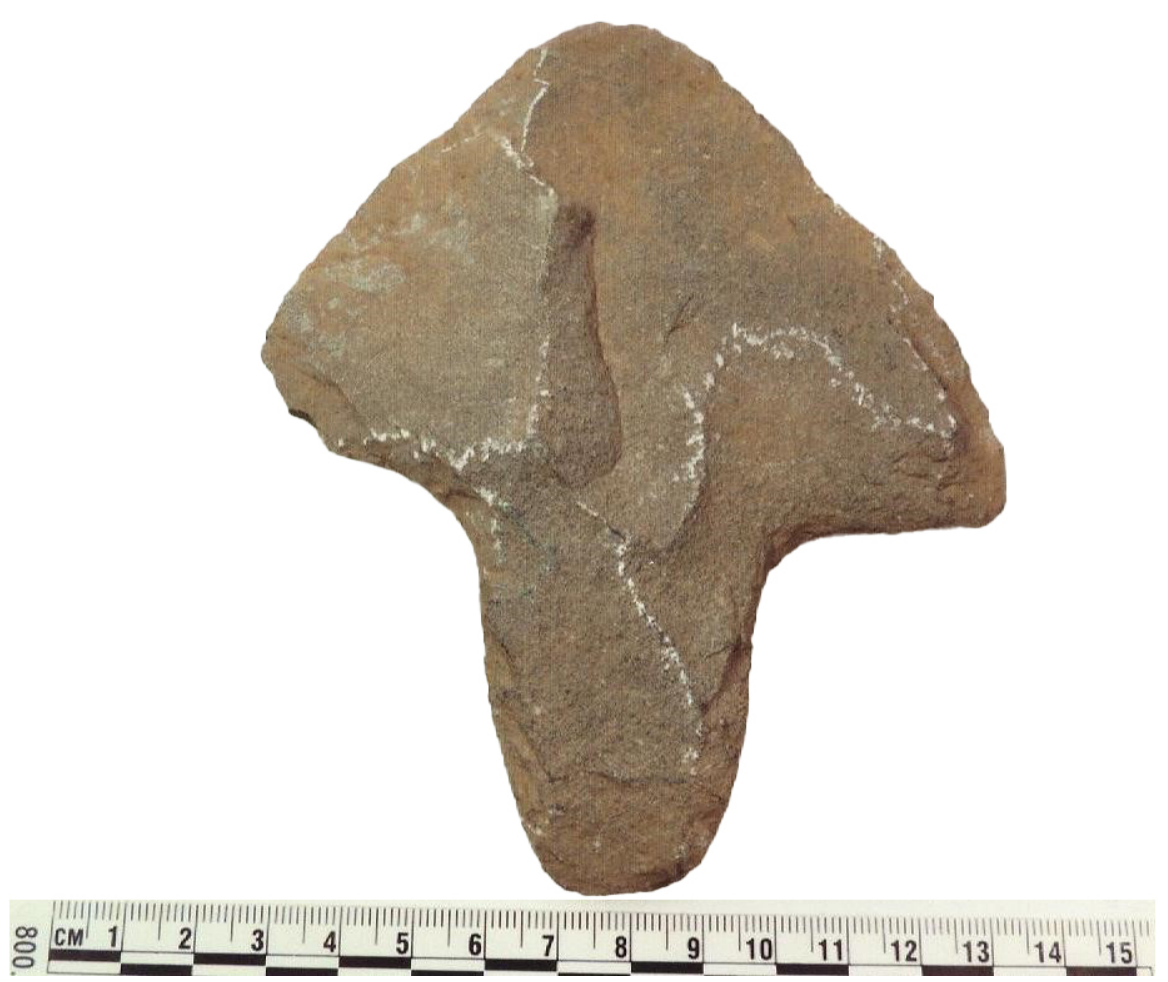

Figure 2. Photograph of Pointed variety (by Healy, courtesy of the Cambridge University Museum of Archaeology and Anthropology; Cat. No. 1946.166N; scale in cm).

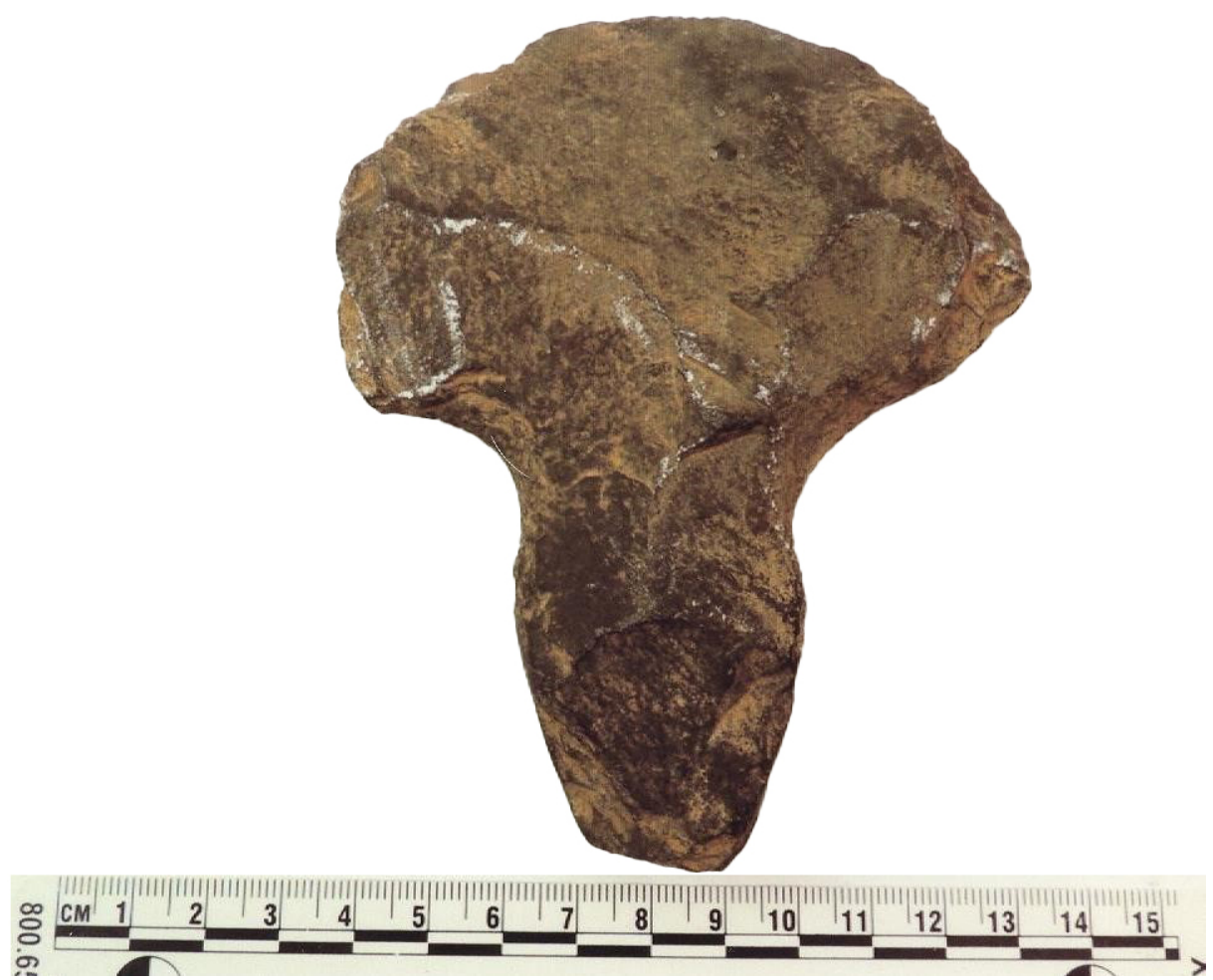

Figure 3. Photograph of Rounded (Crescent or Curved) variety (by Healy, courtesy of the Cambridge University Museum of Archaeology and Anthropology; Cat. No. 1946.166B; scale in cm). 


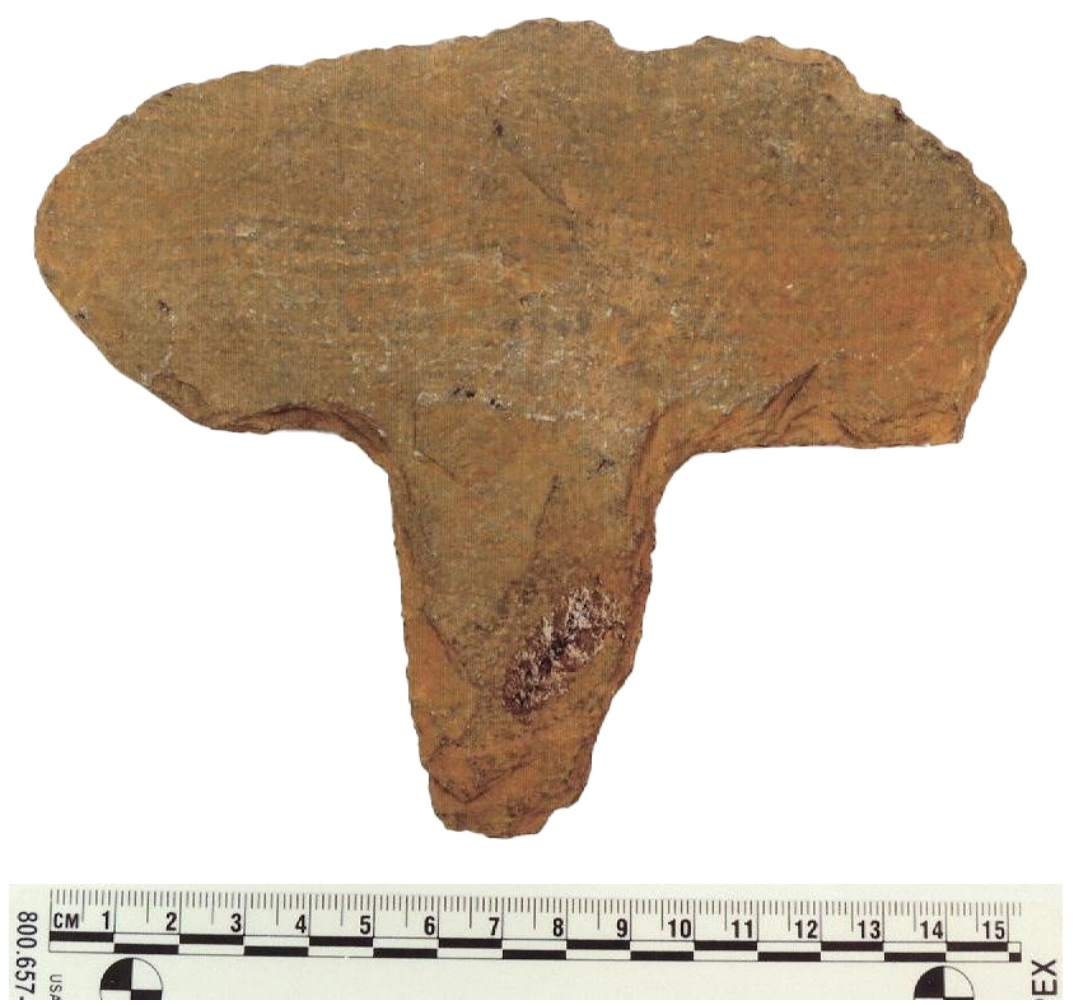

Figure 4. Photograph of Wide (or T-shaped) variety (by Healy, courtesy of the Cambridge University Museum of Archaeology and Anthropology; Cat. No. Z35260F; scale in cm).

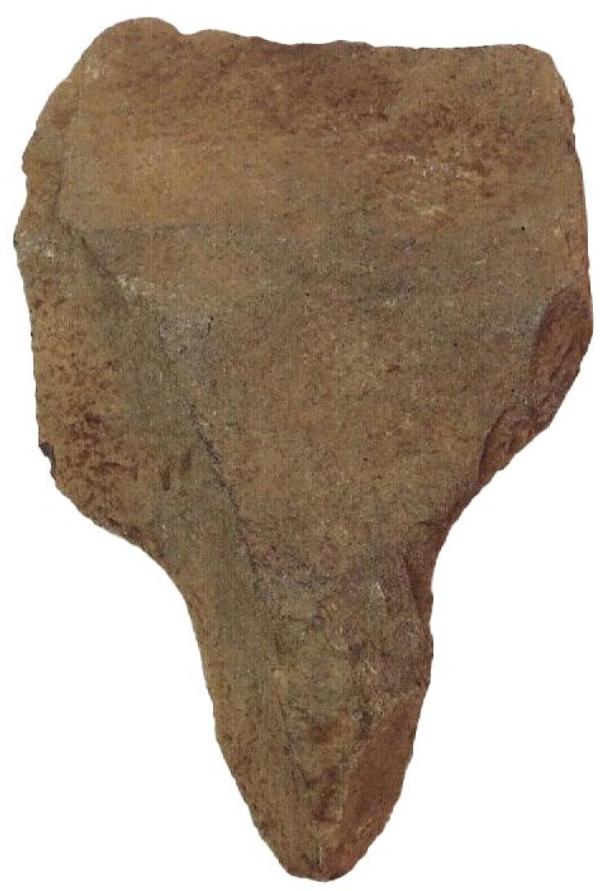

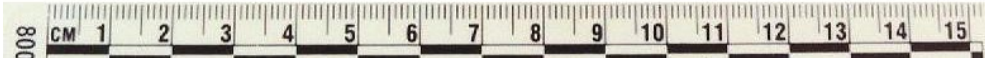

Figure 5. Photograph of Squared variety (by Healy, courtesy of the Cambridge University Museum of Archaeology and Anthropology, Cat. No. Z35258B; scale in cm). 
Thirty-seven (97.4\%) of the 38 Moyne-Feachem specimens examined appear to be made on a dense, foliated, igneous rock composed primarily of plagioclase feldspar within a fine, dark groundmass of what may be pyroxene. Phenocrysts of quartz or olivine punctuate a crystal fabric that can otherwise be described as linear or plano-linear (following Adams et al. 2009: 45). In sum, the material appears most consistent with a fine-grained gabbro or diabase (dolerite). Geological identification of the raw material employed in the so-called T-shaped axes was provided by Dr. Michael Gorton, Department of Earth Sciences, University of Toronto, based on macroscopic examination and visual comparisons with identified geological specimens.

In spite of its foliated geological structure, the raw material had a conchoidal fracture pattern. The one exception (for raw material) in the Moyne-Feachem collection of T-shaped axes was a smaller rounded variety of tool made of white to honey-brown chert, and covered in part by a white limestone cortex (Figure 6). Chert and obsidian are not found locally, and were almost certainly imported from afar (Healy et al. 1996). They occur in archaeological assemblages of the region, but are uncommon.
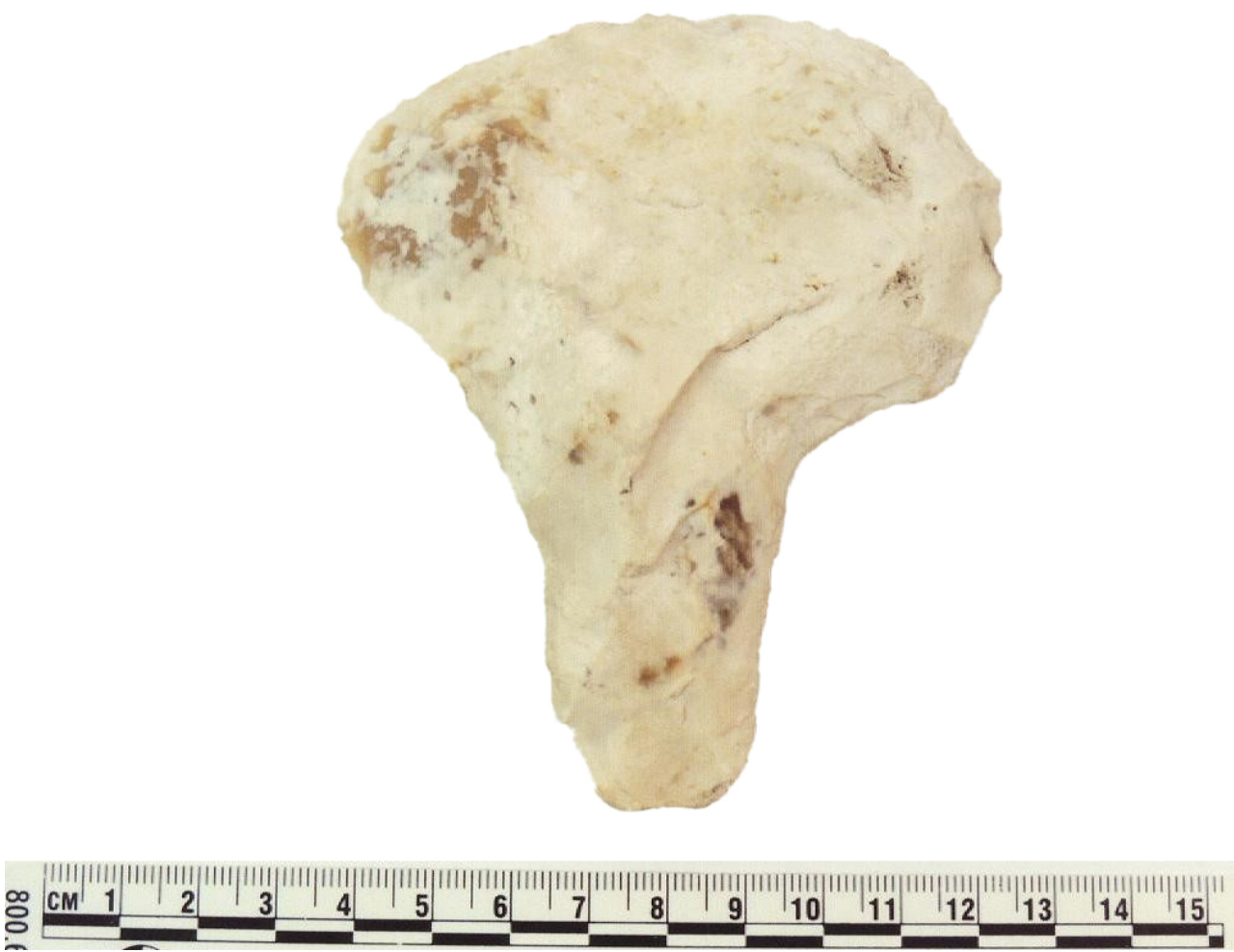

Figure 6. Photograph of Rounded variety made of chert (by Healy, courtesy of Cambridge University, Museum of Archaeology and Anthropology, Cat. No. 1946.166A; scale in cm).

Technologically, all the axes appear to have been produced by percussion flaking, with large scars derived from chip removal, visible on both faces. There are indications that the tools were made, initially, as a single, large, flat flake $(>10 \mathrm{~cm}$ long, and sometimes as much as $20 \mathrm{~cm}$ ) that was struck from a core. These large flakes were probably about three-quarters as wide as they were long. Chipping is bifacial on these large flakes. The narrower tangs often show signs of minor retouch, perhaps designed to straighten one or both lateral edges of the stem. Evidence of the original, prepared (even ground) striking platform, can sometimes be found on the tip of some tangs (Figure 7). This suggests that initially there was a core that was carefully prepared with a multi-faceted striking surface. There tends to be a crude, raised, central ridge down one face of most of the whole specimens, with the reverse side a much flatter face. In this regard, they are vaguely reminiscent of the large plano-convex, stemmed 
macro-blade points from the Southern Maya Lowlands (e.g., Guatemala, Belize, Southern Mexico).

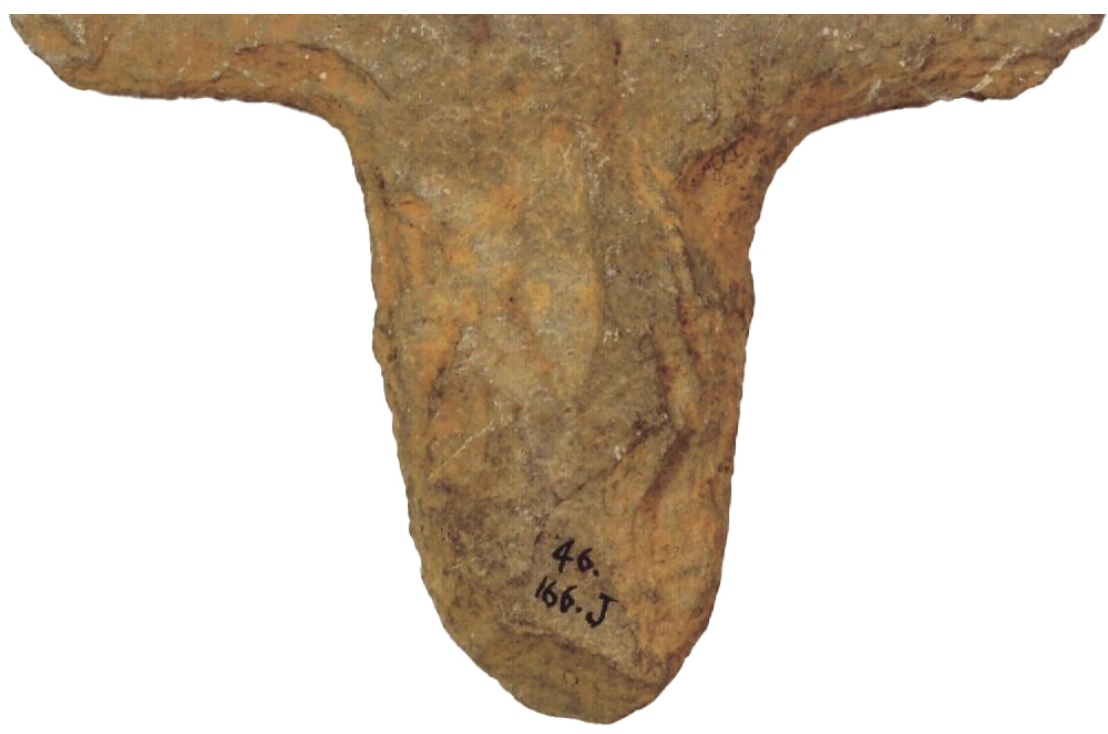

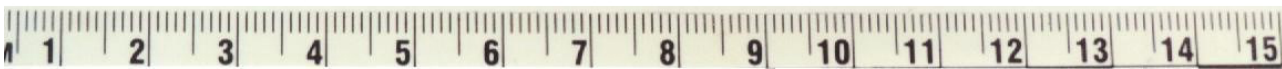

Figure 7. Close-up photograph of tool tang end with prepared striking platform visible just below catalogue number (by Healy, courtesy of the Cambridge University Museum of Archaeology and Anthropology, Cat. No. 1946.166J; scale in cm).

These, however, were much more finely crafted, and uniformly made from chert, rather than gabbro (Shafer 1991: 33-38). One axe blade specimen (Cat. No. 1946.166D) bore a biconical drill hole in the center of the blade, presumably to assist with hafting (Figure 8). Another Squared variety example (Cat. No. $1946.166 \mathrm{~K}$ ) showed signs of significant blade grinding and even some polishing. Most specimens, however, lack a smooth, sharp, blade edge.

Unfortunately, none of the specimens in the Moyne-Feachem collection are identified to their original context or provenience (not to site, or even to a particular island among the Bay Islands). We know that both Moyne and Feachem visited (and collected from) most of the islands in 1937 and 1939 but, with only a few exceptions (none being chipped axes), individual artifacts were not identified to their original location (Feachem 1947).

\section{Comparisons from Elsewhere in Northeast Honduras}

So-called T-shaped axes (also termed spades or choppers) have been reported by archaeologists previously from sites on both the Bay Islands and the adjacent Honduran mainland, about 15-60 km away. William Duncan Strong (1935: 69, plate 19, fig. 2), in one of the earliest, detailed archaeological surveys of the region, reported the presence of six axes found at various sites on Barburata Island (1 specimen), Roatan Island (1 specimen), and Helena Island (4 specimens) of the Bay Islands. Strong (1935: 69) described these unusual hard stone implements as "crudely worked" and made of "indurated shale", "felsite" and "diabase porphyry". The specimens (today housed in the Smithsonian Institution) had a "rounded cutting edge" and displayed signs of heavy use (Strong 1935: 69). Although not stated as such, the implication was that these island lithics, which showed signs of both 
chipping and grinding, were for forest clearing or wood-working. Strong's early study also shows that this tool type occurred on different islands.
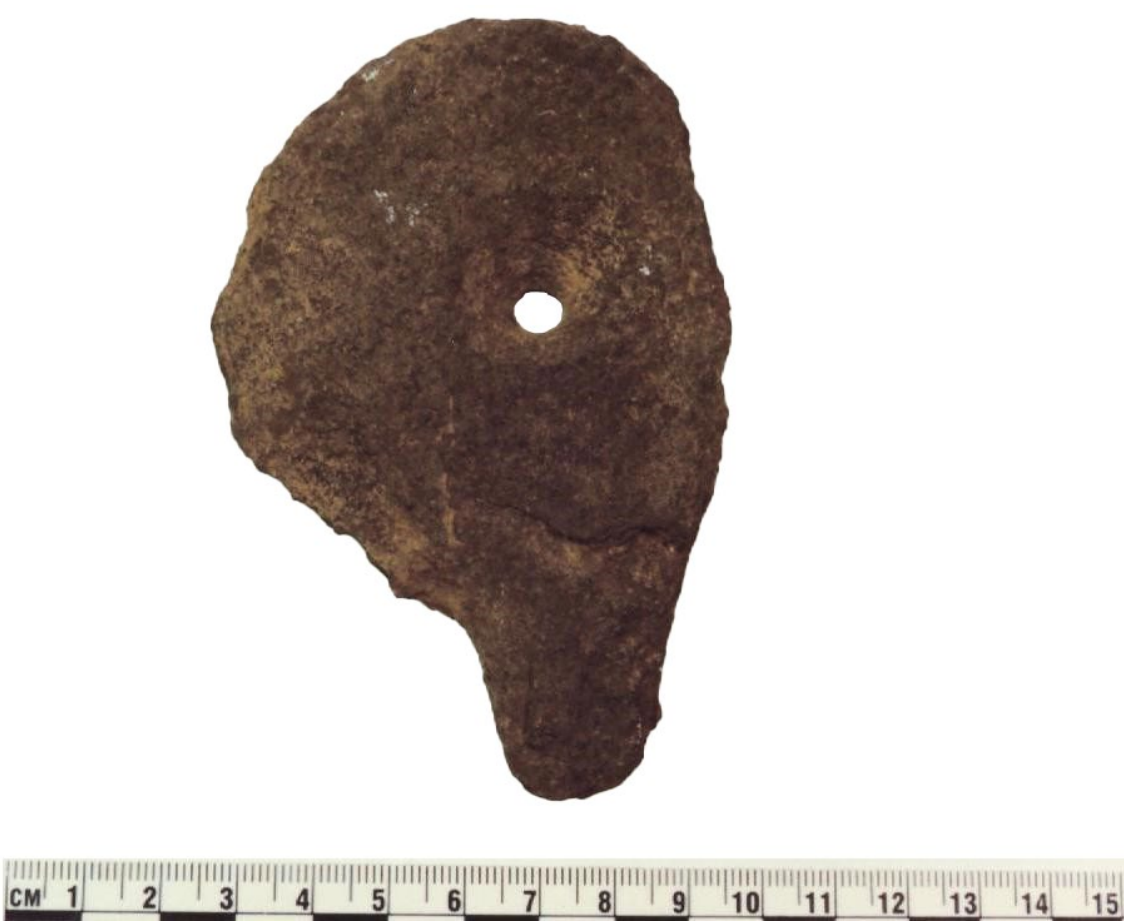

Figure 8. Photograph of Rounded variety fragment with bi-conical drill hole through the blade (by Healy, courtesy of Cambridge University Museum of Archaeology and Anthropology, Cat. No. 1946.166D; scale in $\mathrm{cm})$.

Strong (1935: 148) noted in his report, published by the Smithsonian, that he had seen similar T-shaped axes in collections of the American Museum of Natural History (New York City), which reportedly came from sites along the Paulaya River, about $100 \mathrm{~km}$ east of Trujillo, capital city of the mainland Department of Colon. This was the first suggestion (in print) that this distinctive lithic implement occurred on both the islands and the nearby north coast of Honduras.

The presence of these distinctive implements on the mainland was confirmed a few years later by Doris Z. Stone (1941: 51, figs. 41e to f) in her early, landmark study of the archaeology of Northern Honduras. Like Strong, she described the implements as a type of axe, and the two specimens noted came from excavations of low house mounds near Guaimoreto Lagoon, near Trujillo, and the Aguan River (a major waterway in the region). While there was no discussion by her about the technology used to produce the mainland implements, her published photographs suggest the same chipping methodology as seen from the Bay Islands and published by Strong. There was no geological identification of the material used in the Guaimoreto Lagoon specimens; however, the illustrations suggest a hard, slate-like material which Stone (1941: 51) notes could "be gathered from any mountain stream" nearby. The raw material for the axes was, in other words, local, and not imported. Interestingly, one of the two North Coast specimens had a hole drilled through the shaft as is evident also in one of the CUMAA examples studied (Figure 8). Stone (1941: 51) described this as "...the point at which the handle (no longer present) and blade join. The hole must have been made for the insertion of a pin to secure the handle”.

It was almost four decades later before three investigators provided further information about these distinctive lithics. Reyes Mazzoni \& Véliz (1974), two Honduran archaeologists, published a short account in a local magazine about artifacts that had been looted (and which 
were recovered later by authorities) from a remote cave, near Cuyamel, in Northeast Honduras. While a number of unusual ceramic artifacts were noted among the confiscated goods, Reyes Mazzoni \& Véliz (1974: 18) briefly describe the recovery of 55 flat, stone implements described by them as axes - hachas -, or hoes - azadas. These match the description of T-shaped axes published earlier by Strong (1935) and Stone (1941). One illustration shows a (detached) wooden handle (mango de madera) with an associated slatelike blade implement (Reyes Mazzoni \& Véliz 1974: fig. 22). The authors suggested that the wood handles were originally hafted to the tang end of the blade and, presumably, would have originally appeared much like a modern garden edging or digging tool. They noted that a nearly complete wood handle, measuring $125 \mathrm{~cm}$ long (4 cm diameter), was actually still attached to one of the looted blades in this fashion, and that there were six other wood handle fragments recovered, reputedly from a cave near Cuyamel. As best we are aware, none of these handles has been dated by radiocarbon analysis. Reyes Mazzoni \& Véliz (1974) noted that broad, pointed blades (punta ancha esquinas pronunciadas) were the most common variety in the confiscated collection, with triangular pointed (punta triangular), squared (punta plana) and rounded (punta redonda) blades being next most popular, in order of frequency. These varieties are similar to the forms in the Moyne-Feachem collection in England. Unfortunately, examples (photographs or illustrations) of these individual types (grupos) were not provided, making comparisons inexact.

Shortly after the 1973 looting incident was reported, one of the authors (Healy) of this report visited the Cuyamel region, about $13 \mathrm{~km}$ (directly over the Cerro de Calentura mountain range) south of modern Trujillo, and found several, difficult to reach, caves sites. One of these (H-CN-13: Matilde's Cave) had an array of pre-Columbian artifacts in the cave chambers. These items ranged in age, based on ceramic comparisons, to well dated pottery types in Mexico, from as early as 1000 BCE until contact (ca. 1525 CE) (Healy 1974; 1993). Among these artifacts, most of which were lying exposed on the cave floor surfaces, were two T-shaped axe blades. These measured approximately $14 \mathrm{~cm}$ long, $15 \mathrm{~cm}$ wide, and $2.5 \mathrm{~cm}$ thick (no wooden handles were found). According to a local guide, a cache of these implements, along with long wood handles, had been removed from the site about a year earlier. Presumably, these were the same specimens that were recovered by authorities at the Instituto Hondureño de Antropología e Historia in Tegucigalpa and later described by Reyes Mazzoni \& Véliz (1974).

Several years later, Healy (1978a; b) reported the recovery of this same type of stone tool in some of the first stratigraphic excavations conducted in Northeast Honduras. These occurred at two sites on the mainland, in the Department of Colon: Selin Farm (H-CN-5) and Rio Claro (H-CN-12). The research here also generated the first radiocarbon dates for the region as well. Both sites produced examples of the distinctive lithics that were (again) labeled as T-shaped axes. At the Selin Farm site, not far from the Guaimoreto Lagoon, two of these stone implements were excavated from the uppermost levels of Mound I, the largest (4 $\mathrm{m}$ tall) earth- and shell-layered mound at the site. They measured 11.3 and $16.8 \mathrm{~cm}$ in length, 14 and $15.5 \mathrm{~cm}$ wide, and 1.8 and $2.5 \mathrm{~cm}$ thick, respectively. The mound was interpreted as a substructure for a perishable (probably pole-and-thatch) residence once located on top. The lithics were found alongside decorated ceramics that suggested a chronological placement in the Transitional Selin to Early Cocal period of the regional chronology. A single C-14 date of $745 \pm 60 \mathrm{CE}$ (charcoal sample) was removed from the level, along with a green, serpentine bead, small ceramic figurines, and mano and metate grinding tools (Healy 1978a: 60, table 1). This investigation, then, provided the first evidence for the possible age and chronological placement of the T-shaped axes of Northeast Honduras, and suggested that the tool type was present in this region by the end of the Selin period, specifically during the Transitional Selin period (800-1000 CE). Importantly, this was (as the period name implies) a time of major 
social transformation, with marked changes in the material culture for this region (Healy 1984b; 1984c; Healy \& Dennett 2006).

From the Rio Claro site, a much larger settlement located in the Aguan River Valley, and about $14 \mathrm{~km}$ (direct line) south of Trujillo, Healy (1978b: fig. 13) reported the recovery of four additional "crude, T-shaped axes" which were "directly associated with Rio Claro house mounds." These chipped stone specimens were described as being made of "a heavy, largely unground basalt." (Healy 1978b: 24) The implements measured "no larger than $17 \mathrm{~cm}$ in total length, with cutting blade edges up to $12 \mathrm{~cm}$ wide” (Healy 1978b: 24). Six radiocarbon dates from Rio Claro place the site (at large) as firmly in the Early Cocal period (1000-1400 CE).

Clearly, based on radiocarbon dates from Rio Claro, T-shaped axes, while first appearing in the still poorly defined Transitional Selin period (800-1000 CE), continued into the succeeding Early Cocal period (1000-1400 CE). Healy \& Dennett (2006; see also Hoopes 2005; Hoopes \& Fonseca 2003) have argued that Northeast Honduras, late in this prehistoric era, was a region which was increasingly under the cultural influence of native groups of the Isthmo-Colombian culture area to the south of modern-day Honduras. Interestingly, at the time of first contact with the Europeans, the Paya native population of Northeast Honduras was known to have spoken a Chibchan- (not Mesoamerican-) derived language (Begley 1999; Constenla Umaña 1991; 1995; 2000; Holt 2000; Sapper 2000). While this does not (by itself) prove an ethnic and cultural linkage at this time between Northeast Honduras and Chibchan indigenous groups further south, it is a further line of evidence that contacts occurred between these two regions, Central America and South America (Colombia), some time before the Spanish Conquest.

\subsection{Other regional comparisons}

Are prehistoric T-shaped axes found elsewhere in Central America? A survey of archaeological reports suggests that this type of stone implement, outside of Northeast Honduras, is rare. The only identified examples that are even similar occur in Costa Rica, some $700 \mathrm{~km}$ to the south.

In one of the earliest archaeological studies undertaken in Central America, Carl V. Hartman (1901: 185-186) reported the recovery of a large number of stone objects, including "chisels", from the site of Orosi, in the Central Highlands-Atlantic Watershed zone of Costa Rica. Hartman suggested that the tools might have been employed for cutting stone slabs that, along with earthen mounds, marked the site (a coffee plantation at the time of the research). The report illustrated at least three lithic specimens that are reminiscent of the Northeast Honduras T-shaped axes (Hartman 1901: plate 50 No. 7; plate 67 Nos. 4 and 5), and one specimen that appears very similar (Hartman 1901: plate 67 No. 3). Based on the ceramics from the site, the remains here likely date to the Late period (1000-1550 CE) of Costa Rican archaeology. Hartman (1901) noted that some of the graves he excavated at Orosi contained gold and copper objects (including copper bells and rolls of copper sheet), an obsidian blade, and even European glass beads. The ceramics found, and metals and glass objects, reinforce a very late pre-Columbian or even into the Historic or Contact period. The presence of a worked piece of obsidian suggests possible trade with the north, with identified archaeological sources for obsidian in southern Honduras, Guatemala, and Mexico (Healy et al. 1996).

From a private collection, Snarskis (1981: Catalogue No. 52) illustrates a more refined, ground stone "axe facsimile", likely derived from a site in the Guanacaste-Nicoya region of northwest Costa Rica, and dating to $c a$. 200-500 CE. The specimen $(27.8 \mathrm{~cm}$ in length, $19 \mathrm{~cm}$ wide) is larger and better made than T-shaped axe specimens from Northeast Honduras. However, the shape of the blade is similar, and it appears to have been hafted lengthwise 
(with drill holes in the tang shaft for attachment to a handle), as is the case with some of the specimens from Northeast Honduras.

\section{Discussion and Interpretations of the Data}

\subsection{Dating}

While the Cuyamel Caves are known to have some of the earliest ceramic remains from Honduras (Healy 1974; 1984a; 1992; Reyes Mazzoni \& Véliz 1974), ca. 1000 BCE, they also were utilized for many centuries afterwards, likely as ceremonial and ritual foci. Materials from both the Selin and Cocal periods are known to have come from the caverns. As such, while it is tempting to date the T-shaped axes as far back as the first millennium BCE, there is no direct association (so far) between these distinctive wide blade implements with the earliest ceramics in Honduras. They could just as easily date to a later pre-Columbian period.

Instead, based on the information from the excavations at the Selin Farm and Rio Claro sites, it appears that these coarse lithic implements first occur in Northeast Honduras about $800 \mathrm{CE}$, but continued in use for centuries, until at least $1400 \mathrm{CE}$, a span of about 600 years. This is the first attempt to assign a chronological date to these particular lithics.

\subsection{Function}

The occurrence of the tools within what is presumed to have been a household setting, at excavated sites, and their abundance at sites of both the mainland and adjacent islands, suggests a domestic or utilitarian function. While earlier writers, including one of the authors (Healy), have referred to these distinctive implements as axes, none of the specimens examined from the Moyne-Feachem collection have a particularly sharp, cutting edge. The raw material is not fine-grained, such as obsidian or chert, nor particularly suited for cutting and slicing tasks. Furthermore, sharper, better designed, petaloid celts of basalt have been identified from the region during this time period (Stone 1941: fig. 41a-c; Strong 1935: 79, plate 16a-j). Such wedge-shaped celts, surely once hafted to wooden handles, would have been far superior for tree-felling or related wood-working activities.

By the same reasoning (lack of sharp cutting edges), it is unlikely that these coarse, heavy tools were employed as weapons. The Selin Farm site is located in a very open, accessible location, not far from the lagoon and the coast. By contrast, the younger site of Rio Claro shows signs of fortification (a hilltop location, and a ditch-like construction surrounding most of the site, with a likely palisade and restricted, gated entrances. At the time of exploration of what is today Northeast Honduras by Hernando Cortés, about 1525 CE, following an epic overland trek from highland Mexico, the local inhabitants fled from the Spanish (without resistance), perhaps suggesting a peaceful nature to the culture (Cortés 1960). Unfortunately, there is little known about pre-Columbian warfare in this region.

Reyes Mazzoni \& Véliz (1974: 18) noted that the blades looted from Cuyamel (and recovered by officials) showed little sign of use (estas hachas no muestran uso). This suggested to them that the blades could have been cached in the cave, perhaps as an offering (ofrenda). Alternatively, they may have been placed there for safe storage but were, for whatever reason, never retrieved. Certainly, the examples from the Moyne-Feachem collection show abundant signs of use and blade damage.

We offer an alternative interpretation for their function in antiquity. There are multiple lines of evidence that suggest that the indigenous settlers of Northeast Honduras were fully agricultural late in the prehistoric era and into the Contact period. For example, the vivid account of Christopher Columbus' voyage of exploration in 1503 CE to the Bay Islands and adjacent north coast of Honduras, recorded by Peter Martyr, refers explicitly to local native 
use of both maize and yucca (manioc) (Strong 1935: 13). The excavation of traditional ground stone implements, manos and metates in Northeast Honduras, which were used for millennia in Mesoamerica for the processing of corn, also indicates an agricultural economic base for the region, extending back to at least to the Selin period (Healy 1978a: 63). Indeed, this region has produced not only simple "turtleback", basin-like metates, but also much more elaborate, carved and legged specimens. Both enormous, and miniature, legged metates, often with adorno heads and figural bosses, are known from archaeological sites in the region (e.g., Clark et al. 1985; Healy \& Dennett 2006; Helbig 1956; Stone 1941: figs. 27, 34). The elaboration of the form of the metate (and the not insignificant labour involved in producing such carved specimens) suggests a symbolic and ideological importance for early maize farming here. These elaborate, legged metates of Northeast Honduras also hint at linkages with indigenous cultures further to the south, in both Nicaragua and Costa Rica, where similar ornate metates have also been reported (Abel-Vidor et al. 1981: Catalogue Nos. 73-78, plates 48-50; Jones 1992). Striking similarities in decoration of Cocal period ceramics in Northeast Honduras with Late period pottery (e.g., Curridabat and Stone Cist wares) of Costa Rica have also been noted (Healy \& Dennett 2006).

Might these rather unique Northeast Honduras tools, repeatedly termed axes in the archaeological literature, actually have been employed in antiquity as a form of agricultural hoe, for soil preparation and cultivation, rather than forest clearing, wood working, or warfare? The tang-like shaft of the implements could have been hafted vertically, lengthwise, to the end of a wood pole, instead of laterally, for an axe, creating a long-handled spade or hoe for digging, farming, and earth moving. The presence of drill holes in some blades accords well with such an attachment mode to the distal end of a pole.

Preliminary microscopic examination of a single specimen was undertaken at Trent University. (The specimen examined for use-wear analysis was excavated by Healy from the Rio Claro site, and is curated today at Trent University; see Healy 1978: fig. 13 bottom specimen). Based on macroscopic analysis, the geological material of this mainland specimen is identical to that of all but one of the specimens in the Moyne-Feachem collection.

The wear patterns observed on this tool are not sufficiently developed to be diagnostic of a particular contact material (e.g., soil or wood); nevertheless, the distribution of the wear patterns is telling. Observations by one of the authors (Savage) at magnifications of up to 80x were performed using a Nikon SMZ1000 stereomicroscope with incident lighting. An Olympus BHMJ series compound metallographic microscope with axial bright-field illumination was used for magnifications of $100 \mathrm{x}, 200 \mathrm{x}$ and $500 \mathrm{x}$. In both cases, microphotographs were captured using a Canon EOS T3i (600D) SLR camera. Observational methodology and descriptive terminology follow the framework outlined in Adams et al. (2009).

Three overlapping wear patterns indicate that attritional processes were at work along the broad edge of the blade. A series of small step fractures are intermittently distributed along the distal portion of the blade edge. That these fractures are far more prevalent on one face of the tool than the other indicates a use-motion in which the distal end of the blade impacted its target material on an angle, as would be expected with both digging and woodworking tools.

At no point do the opposing faces of the blade meet at a sharp edge, and the blunt crosssection of the edge is further punctuated by stretches where the margins of the crystals show substantial rounding, resulting in a smooth, sinuous surface. This pattern of edge rounding is apparent within some of the step fractures, while others have sharp margins and very little wear at all. This suggests that these fractures were produced concurrently with the edge rounding, most likely by the same wear process. We suspect that the comparative rarity of this wear pattern stems from the propensity of the raw material to fracture, exposing fresh, sharp edges. Patches of rounding are apparent along the entire length of the blade edge, even as it 
curves toward the distal end of the tool. This indicates either that the implement was achieving a notable degree of penetration into its target material, possibly soil, upwards of five centimeters, or that the lateral sides of the blade were somehow involved in its use.

These rounded areas of the blade edge are also associated with a dull micropolish. At magnifications of 100x and higher, this micropolish is apparent as a thin, transparent gloss which is present on all facets of the microtopography, indicating that the edge of the tool was in contact with a material soft enough to wrap around the peaks of the crystal structure, without leveling them in the process. This gloss extends up to $3 \mathrm{~cm}$ from the blade edge, and diminishes rapidly thereafter. The polish on the specimen examined lacks the characteristics described by Cunnar (2007) and Yerkes et al. (2003: 1054, 1057) for either wood-working or soil-working tools. Furthermore, striations are almost completely absent from the working edge.

The narrow, tang-end of the tool is covered in a similar, but less reflective gloss than is present on the broad, flat blade. This gloss is uniform across the entire surface of the tang, and does not change relative to the distance from the edge, or the location on the topography. This pattern suggests that the tang was hafted with a soft intermediary material, such as leather, similar to the configuration proposed by Cunnar (2007: 232). Similar looking, broad blade tools with tangs, from the Easter Islands (Rapa Nui), off South America, were hafted using cord and wedges (Figure 9).

Interestingly, there is no evidence that the blade of this tool was sharpened by grinding, either initially or following the attritional processes of use. Mills' (1993: 405) experimental study of stone axes demonstrates that woodworking tools require a sharp edge to effectively cut through wood. Indeed, many of the axes that he found ineffective for the task appear to have edges that are much sharper than the tool in question. Furthermore, the average thin profile $(22.3 \mathrm{~mm})$ of this tool would make it liable to snap as a result of the lateral stresses associated with the use of an axe: namely, forceful, oblique impacts against a hard material. Mills (1993: 409) makes a similar observation with regard to a hoe-like tool class, known as tchamahias, from the American Southwest. Rather, the arced morphology of the blade in plan view appears best suited to a deep, cutting stroke into a soft target, against which the entire edge of the blade could be brought to bear. This interpretation is supported by the presence of wear on the lateral sides of the blade, well back of the distal working edge.

In sum, the exact function of this ancient Honduran tool type is difficult to determine without analysis of a larger sample, best anchored by a series of replicative experiments. While the form of the tool appears better suited to earth working than wood working, the usewear patterns on the specimen examined here are insufficiently developed to distinguish between the two with certainty. Nevertheless, it is worth noting that many other specimens within the Moyne-Feachem collection appear to have suffered extreme attrition of the working edge, a characteristic of earth working tools noted by both Mills (1993: 407) and Semenov (1964: 129).

While there is a long history of hoes (made of not only stone, but shell, bone, and wood) known from early cultures of the Mississippi River Valley (Cobb 2000; Cobb \& Garrow 1996; Milner et al. 2010; Winters 1981), Northeast North America (Fowler 1973-74; Sturtevant 1968), the American Southwest (Adams 2002; Turney 1924), Melanesia (Nilles 1942-45), and elsewhere, they have not been explicitly identified, previously, from archaeological sites in Lower Central America. 


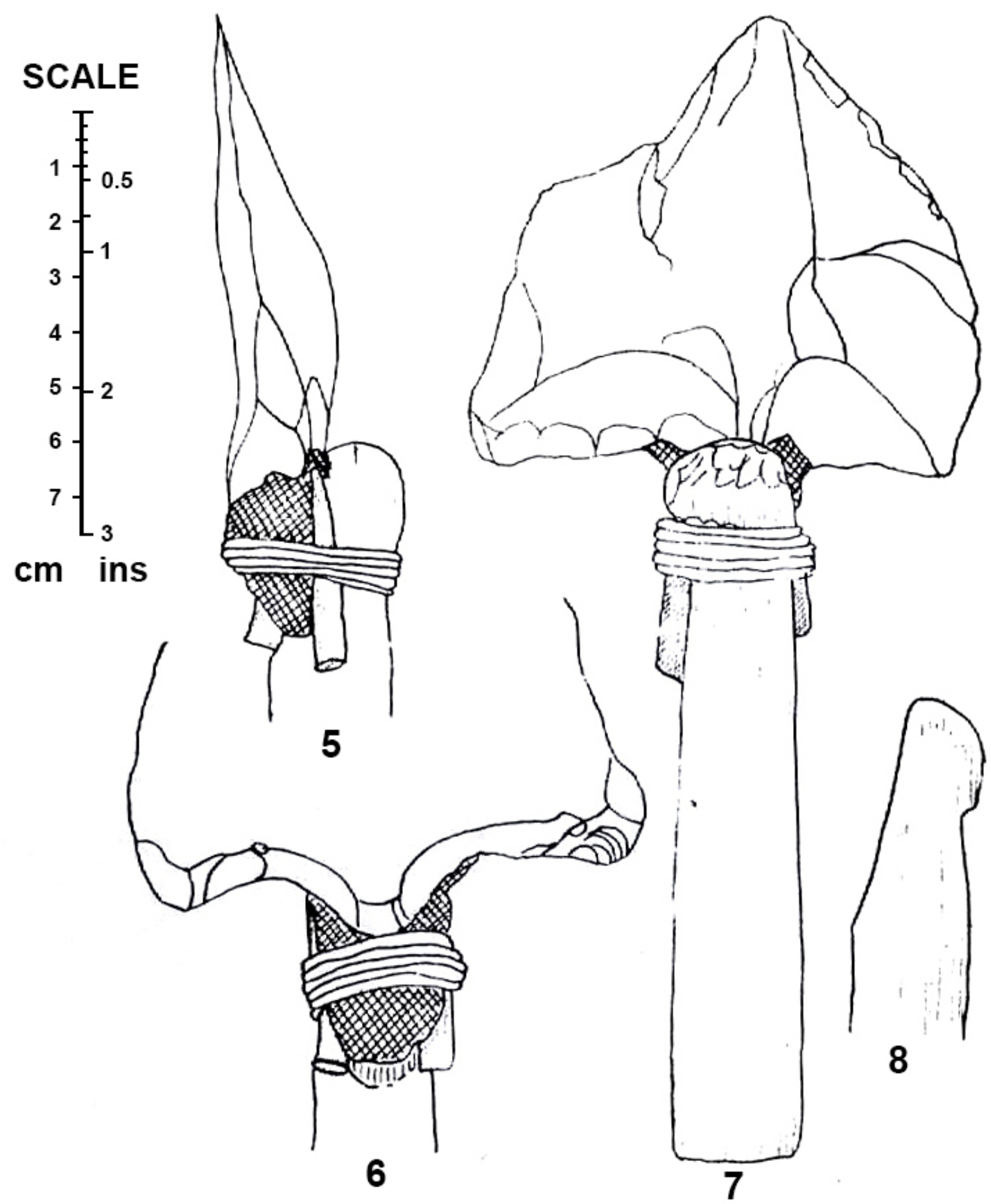

Figure 9. Line drawing of a possible hafting technique (with wedges and cord) for a Pointed variety (by Feachem, after Feachem 1947: fig. 58 No. 5-8).

\section{Conclusions}

In this paper, we have discussed a set of distinctive lithic implements, usually termed Tshaped axes, from Northeast Honduras, Central America. We have described and illustrated some of the 38 flat, chipped (whole and fragmentary) biface specimens that constitute part of a larger collection of artifacts acquired from the Bay Islands of Honduras prior to World War II and now housed at the Cambridge University Museum of Archaeology and Anthropology (CUMAA) (Feachem 1947). These stone axes from the Moyne-Feachem collection are 
categorized into five varieties (Pointed, Rounded or Crescent, Wide or T-shaped, Squared, and Irregular) and compared to previously published descriptions of similar tools, found exclusively at sites in Northeast Honduras. Analysis indicates a very restricted geographic concentration for these unusual implements in Central America, essentially to the Bay Islands and adjacent mainland of Northeast Honduras. This implement has only rarely been found outside the boundaries of this distinctive archaeological region, primarily in Costa Rica (Dennett 2007; Healy 1984b; 1984c; Healy \& Dennett 2006).

While these stone tools have often been labeled in the archaeological literature as axes, their form, coarse raw material, dull cutting edge, and badly worn condition, hint at an alternative function, possibly as flat stone blades hafted to long handles and employed as hoes or spades, for agricultural digging and soil preparation. Specimens from mainland Honduras with an archaeological provenience consistently connect the tools with residential mounds. Fortuitous preservation, and recovery from a cave site, of the elongated wooden handles with a cache of so-called axes suggests hafting that is more suitable for a digging implement, in the service of agriculture and accumulating earth for building earthen constructions, rather than an axe for chopping (Milner et al. 2010). Preliminary wear pattern analysis of one such tool from Northeast Honduras, while not conclusive, does not rule-out a potential use in prehistory consistent with spade-like digging and earth working. From archaeological data and ethnohistoric accounts, ancient indigenous cultures of Northeast Honduras are known to have farmed both maize and the root crop yucca in antiquity. It is argued that the so-called Tshaped axes might, more properly, be classified (and termed in future) as hoes or spades.

Finally, based on stratigraphic evidence from two mainland sites, and associated radiocarbon dates, it is argued that these lithic implements first appeared in Northeast Honduras about $800 \mathrm{CE}$, just as major, external cultural changes were occurring, and that they continued in use until at least $1400 \mathrm{CE}$. Whether they were a local technological innovation, as seems most likely, or introduced from an as yet undisclosed location in Lower Central America, remains to be determined. The lithic type does not resemble any tool types from the Maya or Mesoamerican areas to the west and north. The archaeology of adjacent Atlantic Nicaragua, to the south, is even less well known than that of Northeast Honduras. The closest parallels to these distinctive Northeast Honduras stone tools occur in Costa Rica, far to the south. Given their rarity in Costa Rica, however, it seems plausible that these objects were imported from Northeast Honduras, perhaps as trade items.

More analysis and archaeological reporting of these unique, ancient Honduran stone tools is warranted. Experimental archaeology and a use-wear analysis, in particular, of a large sample of these tools may prove especially insightful to their original function. Until then, they remain a curious early class of stone tools derived from this remote and under-studied region of Central America.

\section{Acknowledgements}

The authors wish to acknowledge and thank two anonymous JLS reviewers who provided useful comments on an earlier draft of this paper. Healy wishes to thank, Imogen Gunn, Curatorial Assistant of the Cambridge University Museum of Archaeology and Anthropology (CUMAA), for kindly providing access in 2012 to the Moyne-Feachem collection, and arranging for laboratory space to examine the lithic implements described herein. Also deserving thanks is Mary Hill Harris, former Curatorial Assistant at CUMAA, who first brought this remarkable collection to the attention of the senior author, and has provided advice and professional assistance over the years. Healy also thanks Daniel Goldberg (State of Craft, Ottawa) for German translations. The Trent University Social Sciences and Humanities Research Council (SSHRC) Committee on Research approved a Sabbatical Grant to Healy for 
this study to be undertaken in England. The paper benefitted from a careful reading of an earlier draft by Dr. Carrie Dennett (Red Deer College, Alberta, Canada), whom we wish to thank. Savage would like to thank Dr. Laure Dubreuil (Trent University) for her comments and advice, as well as the Trent University Archaeological Research Centre (TUARC) and SSHRC for funding and support. The authors alone, however, accept responsibility for any inaccuracies, shortcomings, or errors of interpretation.

\section{Data accessibility statement}

The lithic specimens described herein are presently housed and curated at the Cambridge University Museum of Archaeology and Anthropology (CUMAA). Access to the materials for purposes of research must be arranged through the office of the CUMAA Curator. CUMAA maintains a searchable, online, digital catalogue of artifacts from its collections at: collections.maa.cam.ac.uk

\section{References}

Abel-Vidor, S., Bakker, D., Bishop, R.L., Bray, W., Easby, E.K., Ferrero, A., Fonseca Zamora, O.M., Gamboa, P.H., Gomez, P., Graham, M.M., Lange, F.W., Snarskis, M.J. \& van Zelst, L. 1981, Between continents/between seas: Precolumbian art of Costa Rica. Detroit Institute of Arts \& Harry N. Abrams Inc., New York, 240 p.

Adams, J., Delgado, S., Dubreuil, L., Hamon, C., Plisson, H. \& Risch, R. 2009, Functional analysis of macro-lithic artefacts: a focus on working surfaces. In: Non-flint raw material use in prehistory: old prejudices and new directions (Sternke, F., Eigeland, L. \& Costa, L.J., Eds.) BAR international series Vol. 1939, Archaeopress, Oxford: p. 4366.

Adams, J.L. 2013, Ground stone analysis: a technological approach (Second edition ed.). The University of Utah Press, Salt Lake City, 188 p.

Begley, C.T. 1999, Elite Power Strategies and External Connections in Ancient Eastern Honduras. Ph.D thesis at the Department of Anthropology, University of Chicago, Chicago, $511 \mathrm{p}$.

Begley, C.T. 2000, Commentary 1. In: Early Scholars' Visits to Central America: Reports by Karl Sapper, Walter Lehmann, and Franz Termer (Beaudry-Corbett, M. \& Hardy, E.T., Eds.), Cotsen Institute of Archaeology Press.

URL: http://www.jstor.org/stable/10.2307/j.ctvhhhg6g

Clark, C.M., Dawson, F.G. \& Drake, J.C. 1985, Archaeology of the Moskito Coast: A Reconnaissance of the Pre-Columbian and Historic Settlement along the Rio Tinto. Centre for Latin American Studies Occasional Publication Vol. No. 14. University of Cambridge, Cambridge, 96 p.

Cobb, C.R. 2000, From quarry to cornfield: the political economy of Mississippian Hoe production. University of Alabama Press, Tuscaloosa, 257 p.

Cobb, C.R. \& Garrow, P.H. 1996, Woodstock Culture and the Question of Mississippian Emergence. American Antiquity, 61(1): 21-37. doi:10.2307/282295

Constenla Umaña, A. 1991, Las lenguas del área intermedia: introducción a su estudio areal (1st ed.). Editorial de la Universidad de Costa Rica, San José, Costa Rica, 216 p. 
Constenla Umaña, A. 1995, Sobre el estudio diacrónico de las lenguas Chibchenses y su contribución al conocimiento del pasado de sus hablantes. Boletín del Museo del Oro, 38-39: 13-55. (in Spanish) ("About the diachronic study of Chibcheses languages and it contribution to the past of their speaker")

URL: https://publicaciones.banrepcultural.org/index.php/bmo/article/view/6974

Cortés, H. 1960, Cartas de relación de la conquista de la Nueva España ecritas al emperador Carlos V (facsimile edition). Akademische Druck-u, Verlagsanstalt, Graz, 336 p. (in Spanish) ("Letters Concerning the Conquest of New Spain Written to the Emperor Charles V")

Cuddy, T.W. 2007, Political identity and archaeology in Northeast Honduras. University Press of Colorado, Boulder, Colo, 206 p.

Cunnar, G.E. 2007, The Production and Use of Stone Tools at the Longshan Period Site of Liang-chengzhen, China. Ph.D thesis at the Department of Anthropology, Yale University, New Haven, 881 p

Dennett, C.L. 2007, The Río Claro Site (AD 1000-1530), Northeast Honduras: A Ceramic Classification and Examination of External Relations. MA thesis at the Department of Anthropology, Trent University, Peterborough, 168 p.

Epstein, J.F. 1957, Late Ceramic Horizons in Northeastern Honduras. Ph.D. thesis at the Department of Anthropology, University of Pennsylvania, Philadelphia, 313 p.

Feachem, R.W. 1947, The Material Culture of the Bay Islands. MSc thesis at the Department of Archaeology, Cambridge University, Cambridge, 110 p.

Feachem, R.W. \& Braunholtz, H.J. 1938, Exhibition of Antiquities and Photographs: Antiquities from the Bay Islands, Honduras. Man, 38: 73-74.

Feachem, R.W. 1940, The Bay Islands, Gulf of Honduras. The Geographical Journal, 96(3): 181. doi:10.2307/1788554

Fowler, W.S. 1973, Comparative Study of Hoe and Spade Blades. Bulletin of the Massachusetts Archaeological Society, 35(1-2): 1-8.

URL: https://vc.bridgew.edu/cgi/viewcontent.cgi?article=1118\&context=bmas

Hartman, C.V. 1901, Archaeological Researches in Costa Rica. Royal Ethnological Museum, Stockholm, 195 p.

Healy, P.F. 1974, The Cuyamel Caves: Preclassic Sites in Northeast Honduras. American Antiquity, 39(3): 435-447. doi:10.2307/279432

Healy, P.F. 1975, H-CN-4 (Williams Ranch Site): Preliminary Report on a Selin Period Site in the Department of Colon, Northeast Honduras. Vínculos (Museo Nacional de Costa Rica), 1(2): 61-71.

URL: http://biblioteca.museocostarica.go.cr/articulo.aspx?id=3439\&art=17649

Healy, P.F. 1978a, Excavations at Rio Claro, Northeast Honduras: Preliminary Report. Journal of Field Archaeology, 5(1): 15-28. doi:10.1179/009346978791490013

Healy, P.F. 1978b, Excavations at Selin Farm (H-CN-5), Colon, Northeast Honduras. Vínculos (Museo Nacional de Costa Rica), 4(2): 57-79.

URL: http://biblioteca.museocostarica.go.cr/articulo.aspx?id=3444\&art=17677

Healy, P.F. 1983, The Paleoecology of the Selin Farm Site (H-CN-5), Department of Colon, Honduras. In: Civilization in the ancient Americas: essays in honor of Gordon R. Willey 
(Leventhal, R.M. \& Kolata, A.L., Eds.), University of New Mexico Press; Peabody Museum of Archaeology and Ethnology, Harvard University, Albuquerque, N.M.: Cambridge, Mass: p. 35-54.

Healy, P.F. 1984a, The Archaeology of Honduras. In: The Archaeology of Lower Central America (Lange, F.W. \& Stone, D.Z., Eds.), University of New Mexico Press, Albuquerque: p. 113-161.

Healy, P.F. 1984b, Northeast Honduras: A Pre-Columbian Frontier Zone. In: Recent developments in Isthmian archaeology (Lange, F.W., Ed.) BAR international series Vol. 212, Archaeopress, Oxford, England: p. 227-241.

Healy, P.F. 1984c, The Prehistory of Northeast Honduras: Cultural Change on a PreColumbian Mesoamerican Frontier. National Geographic Society Research Reports, 16: 339-358.

Healy, P.F. 1992, Ancient Honduras: Power, Wealth, and Rank in Early Chiefdoms. In: Wealth and hierarchy in the Intermediate Area (Lange, F.W., Ed.), Dumbarton Oaks Research Library and Collection, Washington, D.C: p. 88-108.

Healy, P.F. 1993, Pottery of prehistoric Honduras: regional classification and analysis. Monograph Vol. 35. Institute of Archaeology, University of California, Los Angeles, Los Angeles, $312 \mathrm{p}$.

Healy, P.F. 2012, Carved Stone Club Heads of Ancient Northeast Honduras: Archaeological Linkages to Costa Rica? Vinculos (Museo Nacional de Costa Rica), 35-36(1-2): 1-18. URL: http://biblioteca.museocostarica.go.cr/articulo. aspx?id=6768\&art=3606274

Healy, P.F., Asaro, F., Stross, F. \& Michel, H. 1996, Prehistoric Obsidian Trade in Honduras and Nicaragua. In: Chieftains, power \& trade: regional interaction in the intermediate area of the Americas (Langebaek, C.H. \& Cárdenas Arroyo, F., Eds.), Departamento de Antropología, Universidad de los Andes, Bogotá, Colombia: p. 14-29.

Healy, P.F. \& Dennett, C.L. (2006). The Archaeology of Northeast Honduras and the IsthmoColombian Area. presented at the 52nd International Congress of Americanists (ICA), Seville.

Healy, P.F., Dennett, C.L., Hill Harris, M. \& Both, A.A. 2010, A Musical Nature: PreColumbian Ceramic Flutes of Northeast Honduras. In: Studien zur Musikarchäologie VII (Eichmann, R., Hickmann, E. \& Koch, L.C., Eds.) Orient-Archäologie Vol. 25, Verlag Marie Leidorf GmbH, Rahden/Westfahlen: p. 189-199.

URL: https://antharky.ucalgary.ca/caadb/sites/antharky.ucalgary.ca.caadb/files/Healy_et _al_2011.pdf

Helbig, K. 1956, Antiguales (altertümer) der Paya-Region und die Paya-Indianer von Nordost-Honduras. Beiträge zur Mittelamerikanischen Völkerkunde Vol. 3. Hamburgisches Museum für Völkerkunde und Vorgeschichte, Hamburg, 40 p. (in in German) ("Antiguales (antiquities) of the Paya region and the Paya Indians of northeast Honduras")

Henderson, J.S. \& Beaudry-Corbett, M., (Eds.) 1993, Pottery of prehistoric Honduras: regional classification and analysis, Monograph Vol. 35. Institute of Archaeology, University of California, Los Angeles (UCLA), Los Angeles, 312 p. URL: https://escholarship.org/uc/item/75z9q032

Holt, D. 2000, Commentary 2 on Ch. 05: The Payas of Honduras. In: Early Scholars' Visits to Central America: Reports by Karl Sapper, Walter Lehmann, and Franz Termer 
(Beaudry-Corbett, M. \& Hardy, E.T., Eds.) Cotsen Institute of Archaeology, Occasional Paper Vol. 18, University of California-Los Angeles (UCLA), Los Angeles: p. 44-45. URL: https://www.jstor.org/stable/j.ctvhhhg6g?turn_away=true

Hoopes, J.W. 2005, The Emergence of Social Complexity in the Chibchan World of Southern Central America and Northern Colombia, AD 300-600. Journal of Archaeological Research, 13(1): 1-47. doi:10.1007/s10814-005-0809-4

Hoopes, J.W. \& Fonseca, O.M. 2003, Goldwork and Chibchan Identity: Endogenous Change and Diffuse Unity in the Isthmo-Chibchan Area. In: Gold and power in ancient Costa Rica, Panama, and Colombia (Quilter, J. \& Hoopes, J.W., Eds.), Dumbarton Oaks Research Library and Collections, Washington, D.C: p. 48-89.

URL: https://antharky.ucalgary.ca/mccafferty/sites/antharky.ucalgary.ca.mccafferty/file s/dwork_and_Chibchan_Identity_-_Gold_and_Power.pdf

Jones, U. 1992, Decorated Metates in Prehispanic Lower Central America, Volumes One and Two. Ph.D. thesis at the Institute of Archaeology, University College London, London, 651 p. URL: https://discovery.ucl.ac.uk/id/eprint/1355098/

Mills, P.R. 1993, An Axe to Grind: A Functional Analysis of Anasazi Stone Axes from Sand Canyon Pueblo Ruin (5MT765), Southwestern Colorado. The Kiva, 58(3): 393-413. doi:10.1080/00231940.1993.11758217

Milner, George R., Hammerstedt, Scott W. \& French, Kirk D. 2010, Chert hoes as digging tools. Antiquity, 84(323): 103-113. doi:10.1017/S0003598X00099798

Nilles, J. 1942, Digging-Sticks, Spades, Hoes, Axes, and Adzes of the Kuman People in the Bismarck Mountains of East-Central New Guinea. Anthropos, 37/40(1-3): 205-212. URL: https://www.jstor.org/stable/40448703

Reyes Mazzoni, R. \& Véliz, V. 1974, La cerámica de Cuyamel. Revista de la Universidad (Universidad Nacional Autónoma de Honduras), Etapa 5(8): 3-26. (in Spanish) ("The Ceramics of Cuyamel")

Rothschild, N.A. \& Cantwell, A.-M.E. 1981, The Research Potential of Anthropological Museum Collections. Annals of the New York Academy of Sciences, 376(1): 1-6. doi:10.1111/j.1749-6632.1981.tb28158.x

Sapper, K. 2000, The Payas of Honduras. In: Early Scholars' Visits to Central America: Reports by Karl Sapper, Walter Lehmann, and Franz Termer (Beaudry-Corbett, M. \& Hardy, E.T., Eds.) Cotsen Institute of Archaeology, Occasional Paper Vol. 18, University of California-Los Angeles (UCLA), Los Angeles: p. 47-54. URL: https://escholarship.org/uc/item/5jp891m6

Semenov, S.A. 1964, Prehistoric technology: an experimental study of the oldest tools and artefacts from traces of manufacture and wear (translated by Thompson, M.W.). Cory, Adams \& Mackay, London, 211 p.

Shafer, H.J. 1991, Late Preclassic Formal Tool Production at Colha, Belize. In: Maya stone tools: selected papers from the second Maya Lithic Conference (Hester, T.R. \& Shafer, H.J., Eds.) Monographs in World Archaeology Vol. 1, Prehistoric Press, Madison, Wis.: p. 31-44.

Sheets, P., Lentz, D., Piperno, D., Jones, J., Dixon, C., Maloof, G. \& Hood, A. 2012, Ancient Manioc Agriculture South of the Ceren Village, El Salvador. Latin American Antiquity, 23(3): 259-281. doi:10.7183/1045-6635.23.3.259 
Snarskis, M.J. 1981, Catalogue. In: Between Continents/Between Seas: Precolumbian Art of Costa Rica (Benson, E.P., Ed.), Harry N. Abrams, Inc., New York: p. 177-227.

Stone, D.Z. 1941, Archaeology of the North Coast of Honduras. Vol. 1. Peabody Museum of Archaeology and Ethnology, Memoir Vol. 9. Harvard University, Cambridge, 103 p.

Strong, W.D. 1935, Archeological Investigations on the Bay Islands, Spanish Honduras. Vol. 14. Smithsonian Miscellaneous Collections Vol. 92. Smithsonian Institution, Washington, D.C, 176 p.

Sturtevant, W.C. 1968, Lafitau's Hoes. American Antiquity, 33(1): 93-95. doi:10.2307/277777

Turney, O.A. 1924, The Land of the Stone Hoe. The Arizona Republican Print Shop, Phoenix, $57 \mathrm{p}$.

Véliz, V. 1978, Análisis arqueológico de la cerámica de Piedra Blanca. Estudios antropológicos e históricos Vol. 1. Instituto Hondureño de Antropología Tegucigalpa, 63 p. (in Spanish) ("Archaeological analysis of Piedra Blanca ceramics")

Willey, G.R. 1959, The “Intermediate Area” of Nuclear America: Its Prehistoric Relationships to Middle America and Peru. Actas del XXXIII Congreso Internacional de Americanistas (ICA-San Jose), 1: 184-194.

Winters, H.D. 1981, Excavating in Museums: Notes on Mississippian Hoes and Middle Woodland Copper Gouges and Celts. Annals of the New York Academy of Sciences, 376(1 The Research): 17-34. doi:10.1111/j.1749-6632.1981.tb28160.x

Yerkes, R.W., Barkai, R., Gopher, A. \& Bar Yosef, O. 2003, Microwear analysis of early Neolithic (PPNA) axes and bifacial tools from Netiv Hagdud in the Jordan Valley, Israel. Journal of Archaeological Science, 30(8): 1051-1066. doi:10.1016/S03054403(03)00007-4 